WETLANDS

THE IEGAL CONTEXT

DENNIS J. DIMSEY

\title{
UMVERSTYY OF MAAYLLAHS LIBRARY
}

Prepared for the

MARYLAND STATE PLANNING DEPARTMENT

July 1968 
8471257

Maryland

$\mathrm{HC}$

107

- 11) 32

no. $148 \mathrm{C}$

Folio 
INTRODUCTION

I - WETLANDS AND FLOOD PLAIN STATUTES OF OTHER STATES

II - RIGHTS OF RIPARIAN LANDOWNERS IN WATERS OWNED BY THE STATE OF MARYLAND

11

A. Waters are Owned by the State

11

B. Rights of a Riparian Owner to Dredge and Make Fast Iand in Waters of the State

III - EXTENT OF THE POWER OF EMINENT DOMAIN

A. Constitutional Limitations on the Exercise of the Power of Eminent Domain

B. State Condemnation of Land for Aesthetic Purposes

C. State Condemnation of Lana for Natural Resources Purposes

D. Measuring Damages Where Land is Taken for a Public Purpose

IV - STATE'S POWER TO REGULATE THE USE OF LAND THROUGH THE POLICE POWER

A. State Liability for Damages for a Restrictive Land Use Policy

B. State Control Over Land Use for Aesthetic Purposes

C. Action by Maryland Counties to Protect Natural Resources

$V$ - LEGAL APPROACHES AVAILABLE TO MARYLAND FOR THE PROTECTION OF THE STATE'S WETLANDS

A. Eminent Domain

B. Acquisition

C. Police Power

D. Flood Plain Zoning 


\section{Digitized by the Internet Archive in 2010 with funding from Lyrasis Members and Sloan Foundation}




\title{
INTRODUCTION
}

In March of 1968 , I was asked by the Maryland State Planning Department to provide answers to legal questions which had arisen in connection with a study of Maryland's wetlands in which the Department was engaged. My job was simply to report the law as it existed; I was not called upon to recommend any particular legislative approach to wetlands preservation.

This report represents the efforts of a third year student at the University of Maryland School of Law over a period of four and one-half months. The questions presented to me and my response thereto follow.

\author{
Dennis J. Dimsey \\ July 31, 1968
}



What have other state legislatures done to protect their wetlands?

This part consists of synopses of the more significant state statutes aimed at protecting wetlands. Since most of these statutes have been enacted within the past several years, there are few court cases discussing them. A brief summary of those few cases which have arisen under the se statutes is included. Comments from state agencies charged with administering a statute are provided in some instances.

\section{CALIFORNLA}

Cal. Fish and Game Code ch. 6, secs. 1600-1602 (Additional Supp. 1967)

General plans sufficient to indicate the nature of a project for construction by a government agency or public utility of any project which will divert, obstruct or change the natural flow or bed of any river, stream or lake designated by the Department of Fish and Game, or which will use material from the stream beds designated by the Department, must be submitted to the Department. When an existing fish or game resource may be adversely affected by such construction, the Department will "propose," and the governmental agency or public utility will "consider," any reasonable modifications in the proposed construction for the protection and continuance of the fish or game resource.

Any person who substantially diverts or obstructs the natural flow or substantially changes the bed, channel or bank of any river, stream or lake, or uses any material from the stream beds, must notify the Department of such operations, except when the Department has been notified pursuant to the preceding paragraph. The Department must submit to the person its recommendations as to the measures necessary to protect fish and wildiife.

\section{CONNECTICUT}

1967 Connecticut Legislative Service. January Session 1967 Public Act No. 536

The State Board of Fisheries and Game is empowered to do the following:

1. Acquire wetlands, or any easements, interests or rights therein, by purchase, exchange, condemnation, gift, devise, lease or otherwise.

2. Enter into agreements with owners of wetlands to conserve wetlands.

3. Enter into leases with an option to purchase wetlands, provided:

a. approval of the Commissioners of Agriculture and Natural Resources is obtained, and

b. the lease does not exceed 10 years. 

4. Take wetlands by eminent domain.

5. Secure title to wetlands by paying to a municipality the amount of the municipality's tax liers on such wetlands, where the municipality's property tax on such wetlands is unpaid for 6 years.

Messrs. Theodore Bampton and Philip Barske of the Connecticut Board of Fisheries and Game commented on Public Act 536 - An Act concerning the acquisition of wetlands.

Mr. Bampton explained that tine Act contains only two new features: first, the Board of Fisheries and Game was empowered to acquire tidal wetlands by exercising the power of eminent domain; second, the Board was authorized to take title to tidal wetlands on which the municipal property tax has been unpaid for six or more years. Plans for the exercise of both of the above options are now being made, but at this time the Board has not yet acquired title to wetlands under the Act. Mr. Bampton believes the Act is a big step forward in the preservation of wetlands.

Mr. Barske was much less optimistic about the Act. He believes the Massachusetts wetland acts have a greater potential for saving wetlands. He noted that Connecticut is "pussy-footing" around the issue because of an emphasis on constitutional rights in that State.

Connecticut General Statutes Annotated, Title 25, ch. 473 , sec. 25-10.

No one may remove sand and gravel from lands under tidal and coastal waters without obtaining a permit from the Water Resources Commission.

Connecticut General Statutes Annotated, Title 25, ch. 473

Sec. 25-4a. The Water Resources Commission is empowered to establish along any waterway or flood plain area lines beyond which no obstruction or encroachment may be placed. The Commission may issue or deny permits for establishing such encroachments based upon its findings.

Sec. 25-4e. After the Commission has established such lines on any waterway or flood plain, any obstruction placed within such lines, without the authorization of the Commission may be enjoined or abated as a public nuisance.

Sec. 25-7d. No one may place a structure or any obstruction within the tidal, coastal or navigable waters of the State without a permit from the Water Resources Commission. The Commission may impose conditions upon the work.

Sec. 25-7e. Any structure violating the above section may be enjoined or abated as a public nuisance.

Sec. 25-7f. Penalty: fine of $\$ 15-\$ 50$, and/or imprisonment from 10-30 days. 

Delaware Code Annoted, ch. 64, sec. 6451-6459 (Additional Supp. 1966)

The Water and Air Resources Commission and the Governor have exclusive jurisdiction to convey a fee simple or lesser interest, to lease or grant permits or easements in or over any parts of the public lands of the State lying beneath the waters of the State, and no use of such lands shall be undertaken except pursuant to a permit or grant.

Each applicant for a lease, permit or grant shall file with the Commission a request containing specifications for any proposed construction.

The Comission shall recommend to the Governor that the application be denied, or be granted on such terms and conditions as the Commission deems just. No lease, permit, deed or other grant shall be executed by the Governor unless it conforms to the recommendations of the Commission but the Governor may refuse to execute any lease, permit, deed or grant in his sole discretion. The permit or grant shall be executed $b_{*}^{*}$ the Governor if he so approves.

\section{FLORIDA}

Chapter 67-393 of the General Acts of 1967

This Act amended the Florida Bulkhe ad Act of 1957 (Florida Statutes, sec. 253.12 et seq.)

Sec. 253.12. Vests title in tidal lands in the trustees of the internal improverent trust fund. The trustees may sell such lands, provided that they determine the sale would not adversely affect public interests, including the preservation of fish and other natural resources. Notice of the sale must be published in the county newspaper. If objections are filed to the sale, a public hearing must be held. If it appears as a result of the hearing that the public interest would be adversely affected by the sale, then the trustees must withdraw the land from sale. A biological and an ecological survey of the land to be sold must be made in determining whether the sale of the land would adversely affect the public interest.

Sec. 253.122. The Board of County Commissioners of each county or governing body of any municipality, after obtaining a biological and an ecological survey, may locate and fix bulkhead lines. Any extension of land outward into the waters of the county is deemed an interference with navigation and the conservation of natural resources.

Sec. 253.123. The removal of sand, rock or earth from the navigable waters of the State and the submerged bottoms thereof Iying channelward of bulkhead lines is not permitted. Certain exceptions are provided for.

Sec. 253.124. Anyone desiring to add to existing land bordering on the navigable waters of the State must apply for a permit to do so. A permit will be issued only if a biological and an ecological survey reveal that the public interest will not be adversely affected. The permit may be revoked 

for non-compliance with its terms. Anyone who violates this section is guilty of a misdemeanor and upon conviction shall be fined a maximum of \$500, imprisoned for not more than 6 months, or both. The trustees have the authority to require the person to remove the fill.

Zabel $\vee$. Pinellas County Water and Nav. Control Authority, I71 So. 2d 376 (1965), on remand 179 so. 2d 370, dealt with sections 253.122 and 253.124 . In this case the local authority lost in its attempt to prevent owners of bottom land from filling approximately 11.5 acres of land to be used as a trailer park. The court held that denial of permission to fill the land amounted to a taking of property without just compensation, because it was not established that granting the permit would materially and adversely affect the public interest.

Florida Statutes Annotated, ch. 375

(Additional Supp. 1966)

This chapter, entitled "Outdoor Recreation and Conservation," empowers the trustees of the internal improvement trust fund to acquire wetlands and floodways by purchase, lease-purchase agreements, or otherwise, with funds from the land acquisition trust fund.

\section{MAINE}

Maine Revised Statutes Annotated, Title 12, ch. 421, secs. 4701-4709. (Additional Supp. 1967)

No one may remove, fill, dredge or drain sanitary sewage into, or otherwise alter any swamp, marsh, bog, beach, flat or other wetland bordering coastal waters, or fill, dredge or drain sanitary sewage into such waters within such area, fithout filing written notice to do so, with plans, to the municipal officers and the Wetlands Control Board. A public hearing is held after receipt of such notice. After the hearing, a permit is issued if the Wetlands Control Board approves. Approval may be conditioned upon the applicant's amending his plans. Approval may be withheld by the municipality or the Board if either body finds the plans damaging to fish life. An appeal is provided for. Anyone viol ating any provision of this statute is subject to a mayimum fine of $\$ 100$. A continuing violation of this statute may be enjoined.

Irr. Richard Parks of Maine's Department of Inland Fisheries and Game commented on Title 12, Chapter 421, of the Maine Revised Statutes Annotated.

He noted that the first individual who was denied a permit to fill a coastal wetland took his case to court, on the ground that the law amounts to a taking of his property without due process of law. Since this case has not yet been decided, Mr. Parks felt that any further comment on the law at this time would be superfluous. 

Maine Revised Statutes Annotated, Title 30, ch. 229, sec. 4001 (Additional Supp. 1967)

Wetlands may be "taken" by a municipality with the consent of the owner and payment of compensation.

Maine Revised Statutes Annotated, Title 30, ch.229, sec. 3801 (Additional Supp. 1967)

Any municipality may receive wetlands as devises or gifts.

\section{MASSACHUSETTS}

Advance Legislative Service to the Annotated Laws of Massachusetts, Number $10(1967)$. 1967 G.I.C. 131, sec. 40. Protection of Flood Plains.

No person shall remove, fill or dredge any bank, flat, marsh, meadow or swamp bordering on any inland waters without filing notice of his intention to do so, with plans of the proposed activity, with the local authority and with State departments of public works and natural resources. A public hearing is provided for. The local authority may recommend protective measures in the public interest, which are submitted to the Commissioner of Natural Resources. If the area where the work is to be done is essential to proper flood control, the Commissioner may impose conditions necessary to protect the public interest, which must be complied with. A continuing violation of this section may be enjoined.

Massachusetts General Laws, ch. 130, sec. 105 (Additional Supp. 1966)

Because of the urgentnecessity of protecting coastal wetlands, the Commissioner of Natural Resources was given the power to adopt, amend, modify or repeal orders regulating, restricting or prohibiting dredging, filling, removing or otherwise altering, or polluting coastal wetlands. Violation of the Commissioner's order is punishable by a fine of between $\$ 10$ and $\$ 50$ and/or maximum imprisonment of one month.

However, if the Commissioner's order so restricts the use of the property as to deprive the owner of its practical use, a court may decree that the order does not apply to that owner's land. In such a case, the Department of Natural Resources may take the land for the State by eminent domain.

Massachusetts General Laws, ch. 40 , sec. 8c (Additional Supp. 1968)

This section empowers a city or town to acquire by gift, purchase, grant, bequest, devise, lease or otherwise the fee or any lesser interest in wetlands and open spaces. It also empowers a city or town to take land by eminent domain for conservation purposes. 

Massachusetts General Laws, ch. 132A, sec. 11

(Additional Supp. 1968)

The State may reimburse a city or town up to $50 \%$ of the cost of acquiring land for conservation purposes pursuant to Section $8 \mathrm{c}$ of Chapter 40 of the Massachusetts General Laws (supra).

Massachusetts General Laws, ch. 130, sec. 27A (Additional Supe. 1966)

No person shall remove, fill or dredge any bank, flat, marsh, meadow or swamp bordering on coastal waters without filing written notice of his intention to do so with the local licensing authority, the State Department of Public Works, and the Director of Marine Fisheries. Restrictions may be placed on such work and such work must be done subject to the se restrictions. Violation of this section is punishable by a maximum fine of $\$ 100$, imprisonment for not more than 6 months, or both. A continuing violation of this section may be enjoined.

Commissioner of Natural Resources v. S. Volpe \& Co., 206 N.E. 2d 666 (Mass. 1965) held that this section does not authorize an absolute prohibition against the filling in of a privately owned marshland if the result would be that the owner would be so deprived of the practical uses of his land as to amount to a taking of the land without compensation.

Whether there had been such a deprivation of the practical uses of the marshland as to be equivalent to a taking without compensation depended upon the uses to which the marshland could be put without violating the statutory prohibition against the marsh. Since the evidence at trial on this issue was lacking, the injunctive decree of the trial court was reversed and the case was remanded for additional findings on the above issue.

Section 27A of Chapter 130 of the Massachusetts General Laws was also construed by the Superior Court (a trial court of general jurisdiction) in the case of Perry $v$. Director of Marine Fisheries (October 23, 1967). The plaintiff in this case gave proper notice to the State of his intention to fill on the shorefront of his property to a depth of one foot. The defendant refused to allow the plaintiff to continue with his project because the area contained shellfish. The court found for the defendant, holding that the refusal did not amount to a taking by eminent domain. The court based its decision on the fact that the value of the plaintiff's property and its practical uses were not diminished by the defendant's order preventing the plaintiff from completing the work. The only effect of the order was to very slightly inconvenience the plaintiff by forcing him, for swimming, to walk a short distance to the public beach adjacent to his property. Plaintiff's rights in his property was held to be subject to the right of the Commonweal th to preserve marine fisheries on such property. 

Mr. Russell Cookingham of the Division of Fisheries and Game of Massachusetts commented on the Massachusetts wetlands acts.

He was of the opinion that protective acts by themselves are not the entire answer to the problem, but that acquisition programs must also be implemented.

\section{MICHICAN}

Michigan Compiled Laws Annotated, sec. 3.651 (1967)

The Great Iakes Commission has the power to recommend policies relating to water resources including the institution and alteration of flood plain and other zoning laws, ordinances and regulations.

Sec. 281.628

Any city, township, etc., may acquire any interest in land necessary to any flood control, drainage or beach erosion control project, or to preserve flood plains, by purchase, gift, exchange, condemnation or otherwise. The legislative body of any such city, township, etc., may institute and prosecute proceedings under the power of eminent domain. The purposes of the Act are declared to be public purposes within the reaning of the constitution, relative to the power of eminent domain.

\section{NEW HAMPSHIRE}

New Hampshire Revised Statutes Annotated, ch. 483-A, sec. 1-5 (Additional Supp. 1967)

No person shall excavate, remove, fill or dredge any bank, flat, marsh, or swamp in and adjacent to tidal waters without notifying the New Hampshire Port Authority of the intention to do so, together with a detailed plan drawn to scale of the proposed project. A public hearing is provided for. The Port Authority may deny the petition or require conditions to protect fish life or to prevent subsequent fill runoff back into tidal waters.

Anyone violating any provision of the statute is liable for the removal of fill, spoil, or structure placed in violation of the statute and shall be fired not more than $\$ 1,000$. A continuing violation of the statute may be enjoined. 

New York Conservation Law, sec. 394 (1967)

This is the Iong Island Wetlands Act. It permits the State to enter into cooperative agreements with towns, villages or counties for the purpose of preserving and maintaining wetlands on Long Island which have been decicated for conservation purposes. The State is empowered to provide one-half of the cost of maintaining such areas.

New York Conservation Law, secs. 429 a-g (1967)

These sections require the issuance of a permit by the Water Resources Comnission before anyone may alter the waters of the State. The Commission may issue the permit subject to conditions upon which the work must be done. The following activities require a permit: altering the channel of a stream, removing materials from a stream, excavating or filling in navigable waters, erecting an impoundment structure, dock or wharf in or across a natural stream or watercourse. A violation of this statute constituted a misdemeanor, punishable by a maximum fine of $\$ 500$, maximum imprisonment of one year, or both.

New York Public Iands Law, art. 2, sec. 3.5 (Additional Supp. 1967)

The Commissioner of General Services may license and regulate the business of taking sand, gravel or other materials in or upon lands urider water and may prescribe the terms and conditions under which the same may be taken. After adoption of regulations by the Commissioner, it shall be unlawful to take or remove from lands of the State under water. any sand, gravel or other material, wi thout a license.

New York Public Lands Law, art. 6, secs. $75-78$

(Additional Supp. 1967)

Enpowers the Commissioner of General Services to grant lands under water to a county, city, town or village for conservation and other purposes.

\section{OREGON}

Oregon Laws of 1967, ch. 421, secs. 109-113

A state official may not issue a permit for the removal of materials from the beds or banks of any body of water which may be utilized or made available to fish, without first notifying the Fish and Gare Commissions of the plans of the operation. The Fish Commission or the Game Commission will advise the state official of possible damage to fish life and they should cooperate to develop a plan to minimize damage. But before giving such advice, the Fish or Game Commission must survey the removal site and determine that the removal will substantially affect fish life. 

The state official cannot issue a permit within 15 days of his mailing notice to the commissions, unless either commission has notified him that it has no interest in the removal or that the materials should be removed subject to specified conditions. Fifteen days after the state official has notified the commissions, he may grant a permit, which "may" contain provisions for the preservation of fish life.

\section{RHODE ISLAND}

General Laws of Rhode Island, secs. 2-1-13 to 2-1-17

(Additional Supp. 1967)

Wetland zoning. Wetland areas are designated and the uses of such areas are restricted to those compatible with fish preservation. Contrary uses may be enjoined.

General Laws of Rhode Island, sec. 11-46.1-1 (Additional Supp. 1967)

Anyone who dumps or deposits mud, dirt or rubbish upon, or who excavates and disturbs the ecology of intertidal salt marshes, without first obtaining a permit therefor issued by the Department of Natural Resources shall be fined for each offense $\$ 100$ : $\$ 50$ to the State and $\$ 50$ to the complainant. The Director of Natural Resources shall refuse to issue such a permit if in his judgment the dumping or depositing of mud, dirt or rubbish or excavation would disturb the ecology of intertidal salt marshes.

\section{VIRGINIA}

Code of Virginia, sec. 62-2.I (Additional Supp. 1966)

With certain exceptions, it shall be unlawful and constitute a misdemeanor for anyone to build, dump, or otherwise trespass or encroach upon or take or use any materials from the beds of the bays, rivers, creeks and the shores of the sea, which are the property of the Commonwealth, without first obtaining authority from the Commission of Fisheries which shall approve or disapprove such request and if approved, shall specify such conditions, terms and royalties as it deems appropriate.

Code of Virginia, sec. 15.1 - 486 (Additional Supp. 1966)

The governing body of any county or municipality may, by ordinance, divide the territory into districts and it may regulate, restrict, permit, prohibit, and determine the use of land buildings, structures and other premises for flood plain (sic) uses. 



\section{WASHINGTON}

Revised Code of Washington Annotated, sec. 75.20.100 (Additional Supp. 1967)

Plans for a project which may divert the flow of water or use materials from beds of water and plans for the protection of fish must be submitted to the Department of Fisheries and the Department of Game. The written approval of both Commissions must be obtained before work is commenced.

The commencement of work prior to such approval, or the failure to comply with the approved plans for the protection of fish life, constitutes a gross misdemeanor.

If a person is convicted of violating this statute and continues the work without complying with its provisions, his work is declared a public nuisance and is subject to abatement as such.

\section{WISCONSIN}

Wisconsin Statutes, ch. 87 , sec, 87.30

(Additional Supp. 1967)

If any county, city or village does not adopt a reasonable and effective flood plain zoning ordinance by January 1, 1968, the Department of Resource Development, upon petition or its own notion, may determine the limits of the flood plains within such county, city or village within which serious damage may occur. The Department will adopt a flood plain zoning ordinance applicable to each county, city or village and such flood plain determination and zoning ordinance shall be of the same effect as if adopted by the county, city or village. The county, city or town may adopt a flood plain ordinance more restrictive than that adopted by the State.

Every structure, building, fill or development placed or maint ained within any flood plain in violation of a zoning ordinance adopted under this section is a public nuisance wich may be enjoined or abated as such. A person who places or maintains any structure, building, fill or development within any flood plain in violation of a zoning ordinance adopted under this section may be fined not more than $\$ 50$ for each offense. Each day during which such violation exists is a separate offense.

Wisconsin Statutes, sec. 59.971

(Additional Supp. 1967)

Counties may, by ordinance, zone all shorelands within the following distances from a nomal high-water elevation of navigable waters: 1,000 feet from a lake, pond or flowage; 300 feet from a river or stream or to the landward side of the flood plain, whichever distance is greater. 

II - RIGHTS OF RIPARIAN IANDOWNERS IN WATERS OWNED BY THE STATE OF MARYLAND

The following questions deal with the rights of riparian landowners in waters owned by the State.

A. What waters in Maryland are owned by the State?

In Maryland, the general rule is that the State is the owner of the land below the high-water mark of navigable waters. Wagner $\mathrm{v}$. City of Baltimore, $210 \mathrm{md}$. 615, 622 (1955). There are two statutory provisions which modify the general rule.

The first is Section 48 of Article 54 (Chapter 129 of the Acts of 1862). This section provides "... no patent shall hereafter issue for land covered by navigable waters." Note: A patent is any valid grant by the State of its interest in land. Article 54, Section 13.7 In the case of Hess v. Muir, $65 \mathrm{Md} .586$ (1886), the court stated that the only effect of this section was to restrict the powers of the Commissioner of the Isand Office.

The second relevant statutory provision is Section 15 of Article $78 \mathrm{~A}$, which empowers the Board of Public Works to issue a patent for land under the waters of the State.

Since Section 48 of Article 54 only restricts the power of the Commissioner of the Land Office to issue patents for lands under navigable waters, it does not conflict with Section 15 of Article 78A, giving the Board of Public Works the power to issue patents for lands under navigable waters. Thus, the rule in Maryland is that the State is the owner of all land below the high-water mark of navigable waters, except for such lands for which the State has issued a valid patent.

There still remains the question of what is a navigable water. In most states, water is deemed narigable if it can be used for purposes of commerce or travel. In Maryland, however, navigable waters are defined as those waters which are subject to the ebb and flow of tides. Thus, in Maryland, those waters which are not subject to the ebb and flow of tides are non-navigable, even if they can be used for purposes of commerce or travel. Linthicum v. Shipley, $140 \mathrm{Md}$. 96, 98 (1922); wagner v. City of Baltimore, supra.

B. To what extent may a riparian owner in Maryland dredge in waters owned by the State and extend his fastland into waters owned by the State?

Although the State is the owner of all lands below the high-water mark of tidal waters, the Legislature has granted tidewater riparians certain rights in these lands owned by the State.

Section 485 of Article 27 gives riparian owners of lands bordering on navigable rivers, creeks or bxanches the right to dig, dredge, take and carry away sand, gravel from the beds of such waters below the high-water mark. This section was strictly interpreted in 51 Opinions of the Attorney General 452. 

The terms "rivers, creeks or branches" were held not to encompass a bay. The words "or other materials" in the phrase "sand, gravel or other materials" were said to include only those grades of submersed soil specially suited for comercial use. Thus this section, as construed by the Attorney General, confers rights only upon riparian owners of lands bordering on navigable rivers, creeks or branches, and the rights conferred are limited to the right to dig, dredge, take and carry away only commercially valuable sand, gravel or similar matter, and not every quality of material in the bed which might be considered suitable fill.

Section 45 of Article 54 gives the proprietor of land bounding on any of the navigable waters of the State the right to all acuretions to his land caused by the recession of the water formed or made "by natural causes or otherwise." 151 Opinions of the Attorney General 4527 stated that this section does not confer upon a tidewater riparian proprietor a general right to fill in front of his property. The Attorney General pointed out that the doctrine of accretion rests upon an increase by imperceptible degrees through natural causes, and does not apply to land reclaimed by man through filling in land under water.

Section 46 of Article 54 gives the proprietor of 1 and bounding on any of the navigable waters of the state the right of making improvements into the waters in front of his land, provided such improvements do not interfere with the navigation of the stream of water into which the improvements are made. 51 Opinions of the Attorney General 452 previously cited also construed this section of the Maryland Code. The Attorney General reviewed the legislative history of Section 46 , as well as judicial decisions construing the section. He concluded that the right to make improvements into the water granted by this section does not confer upon a tidewater riparian proprietor a general right to fill in front of his property. Rather, section 46 was interpreted as granting a tidewater riparian owner only the right to fill up small areas in connection with wharfing out for the purpose of improving the riparian's own commercial access to deep water.

Chapters 690 and 757 of the Iaws of 1965 also affect the rights of riparian owners in land under navigable waters.

Chapter 690 affects only the shorelines of Worcester County. It allows a person, association, or corporation to construct or reconstruct a bulkhead, change a shoreline, or make a fill along the shorelines, but only with a permit from the Worcester County Shoreline Commission.

Chapter 757 concerns only the Isle of Wight Bay and Assawoman Bay in Worcester County. It allows any person, firm, or corporation to pump, dig, excavate, or remove sand or other solid fill materials within certain areas in the Isle of Wight and Assawoman Bays.

The Attorney General, in his letter of June 7, 1968, to the Director of the State Planning Department, was of the opinion that no deed is required from the Board of Public Works to permit an owner of land contiguous to the existing shoreline of Assawoman Bay in Worcester County to bulkhead and dredge in compliance with the provisions of Chapters 690 and 757 of the Laws of 1965. The letter next addressed it self to the question of the extent of 

the owner's title after he has bulkheaded and filled over land which was forrerly under the navigable waters of Assawoman Bay. In answer to this question, the Attorney General stated, "We are unwilling to say categorically that after such bulkheading and filling the title of the State is entirely divested in the land which was formerly under navigable waters, but we feel certain that there is no possibility that the State can be divested of its interest in the land under water in any event until the filling within the bulkhead line has been completed to the extent that the navigable waters have been caused to recede." In effect, the question was left unanswered. 

The following questions deal with the power of eminent domain.

A. What are the constitutional limitations on the exercise of the power of eminent domain?

The Fifth Amendment of the United States Constitution provides in part: "...(N) or shall private property be taken for public use without just compensation." The Fifth Amendment restraint on the power of eminent domain is deemed incorporated by the due process clause of the Fourteenth Amendment of the United States Constitution, and is therefore a limitation on state action, as well as action by the federal government. See Chicago, B \& O R. R. Co. V. Chicago, 166 U. S. 226 (1897), in which it was held that the taking of private property by the state or its agency for a public use without the payment of compensation violates the due process clause of the Fourteenth Amendment.

The concept of public use is broad and includes moral, social, economic, physical, aesthetic, and political wellbeing of the community. Berman v. Parker, 348 U. S. 26 (1954).

A formal condemnation of property by the govemment is obviously a "taking" thereof. However, a taking may also occur when some governmental act causes such a direct and immediate interference with the use or value of the property as to constitute a "taking" thereof.

\section{B. May a state condemn land for aesthetic purposes?}

There are no Maryland cases on the question of whether the State may condemn lands for aesthetic purposes. However, courts in other states have answered this question affirmatively.

In Merced Dredging Co. v. Merced County, 67 F. Supp. 598 (D.C. Cal. 1946), the court stated at page 007: "If the public desires to preserve the scenic or historical features of privately-owned land, the power of eminent domain is available to satisfy the public desire, and the constitutional requirement of just compensation secures the private interests of the owner."

And in Kanrowski v. Siate, 31 Wisc. 2d 256, 142 N.W. 2d 793 (1966), landowners brought an action against the State of Wisconsin to contest the right of the State Highway Commission to condemr scenic easements on lands between a highway and the lississippi River. The Supreme Court of Wisconsin held that scenic easements could constitutionally be taken from landowners by the state, where just compensation was determined and paid.

It should be noted that although the Maryland Court of Appeals has not passed upon the question of condemnation of land for aesthetic purposes, the Maryland Legislature has given its approval to such takings. Sections 236, 237 and 238 of Article $89 \mathrm{~B}$ of the Maryland Code authorize the State Roads Commission to acquire by condemnation strips of land for the enhancement of the scenic beauty of the State. The State Roads Commission, pursuant to these sections, is now in the process of acquiring in excess of one million dollars worth of "scenic lands." 

C. May a state condemn land for natural resource purposes?

Again, there are no Maryland cases on the question of whether the State may condem lands for the purpose of protecting natural resources. However, courts in other states have answered this question affirmatively.

In Pearl River Valley Water Supply District v. Brown, 156 So. 2d 572 (Miss. Sup. Ct. 1963), the court stated that land was taken for a public purpose where it was condemned for pollution control and use as a wildilfe sanctuary, as well as for other purposes.

And in State, Department of Water Resources V. Natomas Co., 49 Cal. Rptr. 64, 239 C.A. 2d 547 (1966) the trial court's statement, that the taking of land for fish and wildlife enhancement was a public use which justified the State's condemnation of the land, was cited with approval on appeal.

D. What is the measure of damages where land is taken for a public purpose?

In Maryland, as in the other states, the general measure of damages in cases where land is taken for a public purpose is the fair market value of the land at the time of the taking. State Roads Commission v. Warriner, $211 \mathrm{Md} .480$ (1957). With respect to the amount of the award, each condemnation proceeding must be judged by its ow peculiar facts and circumstances. C.J.S. Eminent Domain, Sec. 156. 



\section{IV - STATEIS POWER TO REGULATE THE USE OF LAND THROUGH THE POLICE POWER}

The following questions deal with a state's power to regulate the use of land through its police power.

A. Under what circumstances and to what extent may a state be held liable in damages for a restrictive land use policy?

A state's power to restrict the use of privately owned land is an aspect of its police power. Under its police power a state may reasonably restrict the use of an individual's property without payment of compensation to the owner only for the promotion of the health, safety, morals, or general welfare of the community. However, a restriction on the use of private land by a state may be unconstitutional even though the purpose of the restriction is to promote the health, safety, morals, or general welfare of the community. The reason for this is that a state's police power is limited by the constitutional provision that private property may be taken by a state only for a public purpose upon payment of just compensation to the property owner. Thus, if the regulation of the use of property is deemed too restrictive by the court, the regulation will be recognized as a "taking" for which the state must pay just compensation to the property owner. The problem is to determine when the regulations under the police power place such limitations on the use of the property that the enforcement of the regulation amounts, in effect, to a practical confiscation of the land. If the regulation is too restrictive, it will be declared unconstitutional because it authorizes the taking of private land for a public purpose without payment of just compensation to the property owner. If the state still desires to regulate the use of the land, it may take the land by eminent domain, paying just compensation, or it may enact less restrictive regulations.

Land use restrictions may take many forms. Whether valid exercise of the police power for which compensation need not be made often depends upon the facts of the particular case. The following cases are pertinent to the wetlands problem and shed some light on the question of how far a state may go in restricting the use of private land before it will be required to pay compensation to the owner.

The first case to be considered is Morris County Land Improvement Co. v. Township of Parsippany - Troy Hills, 40 N.J. 539, 193 A. 2d 232 (1963). The plaintiff owned 66 acres of swampland which consisted of three layers of materials. The top two layers were very unstable. The bottom layer was composed of sand and gravel and was, on the average, seven or eight feet beneath the surface. The two top layers would not bear structures, were unsuitable for fill and would have to be removed and the land filled with proper material before it could be used for any active purpose, except possibly the raising of fish or the growing of aquatic plants.

In March 1960, the defendant-township enacted a "Meadows Development Zone"l classification. The regulations permitted the following uses as agricultural uses: raising of woody or herbaceous plents, commercial greenhouses, raising of aquatic plants, fish and fish food (with a one-family 

dwelling as an adjunct to any of the se uses, provided its lowest floor was a specified distance above flood level); outdoor recreational uses operated by a governmental division or agency; conservation uses "including drainage control, forestry, wildlife sanctuaries and facilities for making same available and useful to the public;" hunting and fishing preserves; public utility transmission lines and substations; radio or television transmitting stations and antenna towers; and township sewage treatment plants and water supply facilities.

The section went on to provide for uses which may be permitted as special exceptions. A special exception was required for any permitted use which involved a change in any drainage ditch, for the removal of earth products, such as gravel, sand, fill-dirt and peat, and for the diking, damming or filing of any land within the zone.

In August 1960, the plaintiff applied for a special exception in order to fill its lands, to excavate for an 18 -acre reservoir, and to use the material taken therefrom to supply the fill. The application was denied in January 1961, ard the plaintiff filed suit against the township.

The Supreme Court held that the township zoning ordinance constituted a taking of land for a public purpose without just compensation and was therefore unconstitutional.

The court stated that the prime objective of the zone regulations was to retain the land substantially in its natural state. It pointed out that the character of the surface soil was such that it was unsuited for any of the permitted active uses, except possibly the raising of fish and aquatic plants. The court found it significant that, apart from the matter of having to obtain permission subject to exceedingly difficut conditicns, the regulations absolutely prohibited not only removal of the usable top two layers of earth from the zone, but also forbid the importation from outside the zone of suitable fill material. In addition, the court noted that many of the permitted uses in the zone were public or quasi-public in nature, rather than of the type available to the ordinary private landomer as a reasonable means of obtaining a return from his property.

In Dooley v. Town Plan and Zoning Commission, 151 Conn.304, 197 A. 2d 770 (1964), the defendant, the Town Plan and Zoning Commission of the Town of Fairfield, changed the zonal classification of an area of about 400 acres from a residential to a flocd plain district. The plaintiff owned land within the area covered by this change of zone.

In the new flood plain district only the following uses were permitted:

1. Parks, playgrounds, marinas, boat houses, landings and docks, clubhouses and accessory uses.

2. Wildlife sanctuaries operated by governmental units or nonprofit organizations.

3. Farming, truck and nursery gardening.

4. Motor vehicle parking as an accessory to a permitted use in this district or an adjacent district. 

The zoning regulations also forbade the excavation, filling and removal of soil, earth or gravel within the fllood plain district except under a special exception.

The plaintiff brought suit, claiming that the application of the regulations to his property constituted the taking of property without compensation and without due process of law in violation of the fifth and fourteenth amendments of the Constitution of the United States and in violation of the Connecticut Constitution.

The court agreed with the plaintiff's contention and held that the zoning regulations were unreasonable and confiscatory. The court gave five main reasons for its decision.

First - - To restrict the use of privately owned property to parks and playgrounds bars the development of the land for residential or business purposes. The practical effect of this limitation or use is to restrict potential buyers of the property to tow or governmental uses, thus depreciating the value of the property.

Second - - The plaintiff's property was about half a mile from Long Island Sound, and consequently could not be used for a marina, boathouse or landing and dock.

Third - - The regulations permit the use of the property for wildlife sanctuaries operated by governmental unj.ts or non-profit organizations. Such a use dces not provide the landowner with any reasonable or practical means of obtaining income or a return from his property.

Fourth - - The regulations also permit farming, truck and nursery gardening. But a real estate expert testified that farming had Iong been ruled out of the area.

Fifth - - The regulatiors also permit motor vehicle parking as an accessory to be a permitted use in the flood plain district or an adjacent district. However, the court pointed out that the land could not be filled or paved except by special exception granted by the defendant under stringent conditions, and then only for a limited time.

The court concluded that for all practical purposes the zoning regulation rendered the use of the plaintiff's land impossible.

The final case to be considered is Commissioner of Natural Resources v. S. Volpe and Co., 206 N.E. 2d 666 (Mass. 1965). In this case the defendant purchased approximately 50 acres of marshland adjacent to the coastal waters of Wareham, Massachusetts, in 1960. In 1963, sec. $27 \mathrm{~A}$ of Chapter 130 of the Massachusetts General Laws was enacted. Sec. 27A provided in part: "No person shall remove, fill or dredge any bank, flat, marsh, meadow or swamp bordering on coastal waters without written notice of his intention to so remove, fill or dredge to the board of selectment in a town..., to the State Department of Public Works, and to the Director of Marine Fisheries. ... The selectmen ... shall hold a hearing on said proposal... If the area on which the proposed work is to be done contains shellfish or is necessary to protect marine 

fisheries, the said Director may impose such conditions on said proposed work as he may determine necessary to protect such shellfish or marine fisheries, and work shall be done subject thereto... The Superior Court shall have jurisdiction in equity to restrain a continuing violation of this section..."

In October 1963, the defendant notified the appropriate authorities of his intention to dredge a channel through the marsh as part of a project to fill the marsh for the construction of houses. After a hearing the Director of Warine Fisheries notified the defendant that "in the interest of protecting marine fisheries and maintaining the ecological components of this estuarine complex...no fill of any type (may) be placed on the area known as Broad Marsh."

When the defendant ignored the Director's order, the Comnissioner of Natural Resources and the Director of Marine Fisheries successfully brought a bill in equity to enjoin violation of the Commissioner's order and to reouire the removal of all fill placed on the marsh in violation of the order.

The defendart appealed this decision to the Supreme Judicial Court of Massachusetts. The court pointed out that the question presented by this case is analogous to that which arises when the validity of a zoning ordinance is considered (as was the situation in the two cases previously discussed). The court stated that the protection of marine fisheries was clearly a public purpose for which the use of private property may be regulated by the State. The court phrased the issue as "whether, notwithstanding the meritorious characten of the regulation, there has been such a deprivation of the practical uses of a landowner's property as to be the equivalent of a taing without compensation."

Since the trial judge had made insufficient findings on this issue, the case was remanded to the trial court for the taking of further evidence and for further findings on the issue. The court suggested that there be evidence and findings on the uses which can be made of the land in its natural state and the present fair market value of the land, subject to the limitations imposed by the Commissioner and without such limitations, as well as other matters.

B. May a state control the use of land for aestretic purposes?

Since 1926 when the United States Supreme Court first upheld a comprehensive zoning ordinance in Village of Euclid V. Ambler Realty Co., 272 U.S.365 (1926): there has been no doubt that the police poiver of a state could constitutionally be utilized to restrict the use of an individual's property for the benefit of the community in general. Ihere are four universally accepted purposes that justify any use of the police power: the promotion of the health, safety, morals, and general welfare of the community.

Subsequent to this decision zoning ordinances were enacted in many states which sought to regulate the use of private property for purely aesthetic reasons. The issue presented in these cases was whether zoning for purely aesthetic purposes constituted an exercise of the police power for the promotion of the "general welfare" of the community. The position taken in the earlier cases, which is still the view in the vast majority of states 

today, is that zoning for purely aesthetic purposes does not constitute a valid exercise of the police power. However, a zoning ordinance which tends to promote an aesthetic purpose will be upheld if the ordinance also serves to promote the public health, safety, or welfare.

States taking this position include: California, Delaware, Illinois, Iowa, Louisiana, Massachusetts, Michigan, Minnesota, Mississippi, Missouri, Nebraska, New Hampshire, New Jersey, North Carolina, Ohio, Pennsylvania, Tennessee, Texas, Virginia, Washington, and Wisconsin.

In many of these states, zoning ordinances which tend to promote aesthetic purposes are upheld where they have the effect of protecting property values in the community. The protection of property values in the community is considered to be a matter of public welfare. And in Florida, Louisiana, Massachusetts and New Hampshire zoning ordinances based on aesthetic considerations have been upheld where the ordinances have had the effect of promoting tourism.

To date, only two states have held that zoning for purely aesthetic purposes may constitute a valid exercise of the police power.

The first state to adopt this view was New York, in the case of People V. Stover, 12 N.I.2d 462,191 N.E. 2d 272, 240 N.Y.S. 2d 734 (1963). This case concerned an ordinance prohibiting the maintenance of clotheslines in a front or a side yard abutting a street. The court did not base its decision on the protection of property values. The court stated: "Consequently, whether such a statute or ordinance should be voided should depend upon whether the restriction was an arbitrary and irrational method of achieving an attractive, efíciently functioning, prosperous community - and not upon whether the objectives were primarily aesthetic."

In 1965, the Oregon Supreme Court, in Oregon City v. Hartike, 400 P. 2d 255 (Ore. 1965) upheld an ordinance that totally excluded automobile wrecking yards from the city. The court stated: "It must be conceded that authority for the validity of zoning for aesthetic purposes only is scant. People v. Stover...is most directly in point with the instant case. We join in the view that aesthetic considerations alone may warrant an exeruise of the police power."

The Maryland Court of Appeals has made no mention of the validity of zoning for aesthetic purposes. However, mention should be made of Sections 38 to 50 of Article 663 of the Maryland Code. These sections are grouped under the heading of "Historic Area Zoning." The se sections enable the counties of Maryland and Baltimore City, by ordinance or regulation, to regulate the construction, alteration, repair, moving, and demolition of structures of historic and architectural value within their respective limits. Each county and Baltimore City are allowed to establish districts which are deemed to be of historic or architecturai value and nay create "historic district commissions." Anyone desiring to alter the exterior appearance of a structure of historic or architectural value must file an application to do so with the comission. In revieving the plans for any such change, the commission may give consideration to, among other things, "any other factors including aesthetic factors which the commission deems to be pertinent." 

C. What legislative action have the counties of Maryland taken in order to protect their natural resources?

A survey of the codes of the counties of Maryland revealed that little is being done legislatively by the counties for the protection of their wetlands. Only three of the eighteen Maryland counties whose codes were surveyed (the Codes of Carroll, Queen Anne's, Somerset, Talbot and Worcester Counties were unavailable)contaired provisions which seemed pertinent. Sumaries of these provisions follow.

Frederick County Code, Sections 40-57 to 40-63

The se sections establish a conservation district within the County zoning scheme. The uses of land are restricted to those consistent with conservation purposes. These sections provide in part that only those mines, quarries and pits which are worked in such a manner as not to impede the natural flow of any stream or pollute its waters are allowed in a conservation district.

Howard County Code, Section 205

This section creates a Board of Parks, which is empowered to acquire rights in real and personal property for watershed conservation and for the preservation of open spaces and areas for public recreation and enjoyment.

Montgomery County Code

Section 79-31

This section provides that no building permit shall be issued for any structure or alteration of an existing structure on land which lies within the fifty-year flood plain of any stream or drainage course, with the exception that a building permit may be issued for fences, public utilities, recreation and agricultural uses on such lands.

Section 104-21

This section permits the Montgomery County Planning Board to restrict subdivision for development of any property which lies within the fifty-year flood plain of any stream or drainage course, when it deems it necessary to do so for the health, safety, comfort or welfare of the present and future population of the regional district and necessary to the conservation of water, drainage and sanitary facilities. 

What are the legal approaches available to the Maryland Legislature for the protection of the State's wetlands?

\section{A. Eminent Domain}

Several states have enacted statutes which specifically enable municipalities or state agencies to acquire title to wetlands through the exercise of the power of eminent domain. Since just compensation must be paid to the owner whenever land is taken by eminent domain, this approach may be utilized only to the extent that funds may be provided for the reimbursement of those owners whose land is to be taken. A state's power to take land by eminent domain is a well-recognized legal right; authorizing the taking of wetlands by eminent domain is certainly one approach available to the Maryland Legislature.

B. Acquisition

A number of state statutes empower municipalities or state agencies to acquire the fee, or lesser interests, in wetlands. Acquisition by any legally recognized means is usually authorized. Again, unless the acquisition is accomplished by some form of gift, coinsiderable problems of expense may arise.

Maryland has enacted a statute which may authorize the acquisition of wetlands. Section 357A of Article 66C of the Maryland Code empowers any city or county, the Maryl and-National Capital Park and Planning Commission and the State Department of Foresis and Parks to acquire the fee, or any lesser interest, in "open spaces." The definition of "open spaces" includes areas whose natural condition, if retained, would maintain or enhance the conservation of natural resources. It seems that this definition would include wetl and areas.

C. Police Power

Under its police power, a state may regulate the use of its wetlands in any way it sees fit, as long as the means chosen are reasonably calculated to achieve the desired result (i.e., the preservation of wetlands) and as long as the regulation is not so restrictive as to deprive the owner of all reasonable use of his land. As long as the restriction does not amount to a practical confiscation of the land, the state will not be required to compensate the landowner for the limitations placed upon the use of his land.

Statutes regulating dredging and filling in wetland areas are the most common type of police power regulation of wetland uses. Such an approach would not conflict with existing Maryland Iaw. 

Wetlands situated in flood plains may be preserved by means of flood plain zoning ordinances. Wisconsin enacted a statute which provided that if any county, city or town did not enact a reasonable and effective flood plain zoning oroinance by January 1, 1968, a state agency would have the power to adopt such an ordinance applicable to the county, city or village. This approach could be used by the Maryland Legislature to ensure that each Maryland county has a flood plain zoning ordinance which would serve to preserve wetlands located in flood plains. 
